\title{
Antropologia de corpos e sexos: entrevista com Françoise Héritier ${ }^{1}$
}

\author{
Renato Sztutman \& Silvana Nascimento ${ }^{2}$ \\ Doutorandos em Antropologia Social - USP
}

Françoise Héritier faz jus ao seu nome que, em francês, significa "herdeiro". Professora honorária do Collège de France, onde ocupou por muitos anos a cadeira de Estudos Comparados de Sociedades Africanas, ela é considerada a sucessora de Claude Lévi-Strauss, e isto por algumas razões. A mais importante delas diz respeito ao desenvolvimento dos estudos de parentesco e, por conseguinte, à formulação de uma teoria geral do social. Além disso, Françoise Héritier elaborou uma análise sobre a relação entre o masculino e o feminino, que ela chama de "valência diferencial dos sexos", que se tornou uma referência fundamental na área de estudos de gênero franceses.

Em linhas gerais, pode-se dizer que a sucessão em relação a LéviStrauss implicou tanto continuidades quanto afastamentos. Continuidade no sentido de completar o trabalho realizado por ele em As estruturas elementares do parentesco. Se este, ao construir uma teoria geral do parentesco, limitou-se ao estudo das estruturas elementares - aquelas que prescrevem casamentos por meio de regras positivas -, Françoise Héritier pretendeu ir além aproximando-se das estruturas complexas. Mais especificamente, a autora deteu-se num ponto entre o elementar e o complexo, examinando sistemas terminológicos que, se não prescreviam diretamente uniões, ao menos prescreviam proibições. $\mathrm{Na}$ esteira 
das reflexôes de Lévi-Strauss, ela denominou esses sistemas de "semicomplexos" e chegou a eles por meio de sua larga pesquisa de campo entre os Samo do Burkina Fasso, na África Ocidental, que possuíam uma terminologia oblíqua de tipo omaha. A passagem da descrição de um sistema terminológico particular de tipo semicomplexo para a formulação de uma teoria mais ampla do parentesco e, por conseguinte, do social aquela que defende a anterioridade da diferença entre os sexos em relação à própria afinidade - foi desenvolvida em L'exercice de la parenté, livro publicado pela primeira vez em 1981, resultado de cerca de 20 anos de pesquisa.

Os estudos de Françoise Héritier acarretaram também certos distanciamentos decisivos em relação ao estruturalismo lévistraussiano. Ambos os autores convergiram na idéia de que o social é constituído pela diferença. No entanto, se, para Lévi-Strauss, a diferença era dada no imperativo da troca, que é uma propriedade do espírito humano, para Héritier, ela se encontrava num patamar, por assim dizer, menos mental, tal a diferença (assimetria) irredutível entre os sexos, que ela denominou como "valência diferencial dos sexos". A autora deixou para trás o espírito para encontrar-se com o corpo. Assim, a diferença fundamental expressa pelos pares de oposição não advém de um princípio transcendental (para falar com os filósofos) ou de uma forma de funcionamento do cérebro humano (para falar com os neurologistas), mas sim do fato de que os homens observam as diferenças sensíveis - fisiológicas e morfológicas - e, deste modo, constroem o seu pensamento. De certa forma, Françoise Héritier levou às últimas consequiências o argumento lévistraussiano da "lógica das qualidades sensíveis", mas que depende sempre de uma espécie de qualidade irredutível e absolutamente durável: a diferença, reconhecida em toda parte, entre o masculino e o feminino.

Depois de teorizar sobre essa diferença fundamental, por meio de diversos ensaios reunidos no livro Masculin/féminin: la pensée de la différen- 
Revista de Antropologia, São Paulo, USP, 2004, v. 47 no 1.

ce (1992), a autora aventurou-se sobre outro tema lévistraussiano, o incesto. Como em Lévi-Strauss, é a proibição do incesto que instaura o social, ao impor a necessidade da troca. Mas, se Lévi-Strauss salientou o lado intelectual dessa proibição, Héritier focalizou seu caráter substancial, ou seja, o fato de que, em todas as sociedades humanas, o incesto - alvo de repugnância - é concebido como contato entre substâncias idênticas.

É nesse sentido que se descortinou, em Les deux soeurs et leur mère: anthropologie de l'inceste (1994), o que a autora denominou de "incesto de segundo tipo", qual seja, certas interdições que não dizem respeito apenas às mulheres próximas, como mães e irmãs (reais ou classificatórias), mas que se estendem, por exemplo, à mãe e às irmãs da esposa de Ego. Subjaz a essa interdição, que não é universal porém tendencial, a idéia de que se casar com duas esposas consangüíneas pode significar a mistura perigosa de substâncias idênticas. Para Héritier, que recusa o relativismo, produzir uma antropologia dos processos corporais significa extrair das diversas teorias nativas princípios gerais; dentre eles, a idéia de que o incesto é sempre uma recusa da identidade, e que a identidade passa necessariamente por relações substanciais. Se há múltiplas teorias sobre o corpo - e, mais precisamente, sobre o corpo sexuado -, é preciso buscar nessa multiplicidade constantes que advêm da observação de dados biológicos de base. Nesse sentido, Héritier não teve o menor problema em se declarar "universalista": não é possível transformar a base que nos antecede. Não há múltiplos sexos, mas apenas dois, e isto faz a diferença. Ora, essa acepção coloca o Ocidente moderno em relação assimétrica com as demais sociedades do mundo, que a autora denomina como "tradicionais". E isso porque o Ocidente vive, cada vez mais, transformações nas relações entre os sexos, dentre as quais a invenção dos modernos métodos contraceptivos parece ter sido a mais crucial.

Em Masculin/féminin, a autora sugeriu que a "valência diferencial dos sexos" conduz, na maioria dos casos, à dominação masculina. Em toda 
parte, os homens procuram se apropriar de faculdades necessariamente femininas, como a gestação e, o que é ainda mais importante, a possibilidade de produzir tanto o idêntico (uma menina) quanto o diferente (um menino). Desse fato, por assim dizer biológico, decorre uma dominação a um só tempo teórica e concreta (ainda que saibamos que cada sociedade realiza esta dominação das formas mais diversas). Ora, se a diferença entre os sexos está na base, é possível, pelo menos, contornar a hierarquia e restabelecer um patamar de igualdade entre homens e mulheres. Desse modo, Héritier apresentou novas possibilidades de romper com a dominação masculina em Masculin/féminin 2: dissoudre la hiérarchie, livro publicado em 2002, que deu continuidade ao primeiro volume.

Em linhas gerais, ela passou do inexorável da valência diferencial dos sexos para o contornável da dominação masculina e proclamou, assim, a possibilidade de dissolver, em algum plano, a hierarquia. Os modernos, por esse prisma, estariam no olho de uma nova revolução copernicana, dada pela possibilidade, enfim, de as mulheres exercerem controle sobre as suas capacidades reprodutivas e, assim, romperem a sujeição cometida pelos homens.

Ao colocar questôes tão profundas como estas, a obra de Françoise Héritier revela-se de uma grande ousadia. Num tempo de construtivismos, ela, que jamais se distancia da sua formação como africanista e não hesita em discutir assuntos atuais que concernem à sociedade moderna, procura encontrar para eles saídas teóricas e éticas. O que se pode perguntar, no entanto, é se esse seu universalismo, por assim dizer substancial, poderá suportar todos os desconcertos trazidos pela etnologia recente, que não cessa de colocar de ponta-cabeça noçôes como poder, propriedade e direito, tão caras ao pensamento moderno, e que se vêem fortemente presentes na sua obra. De todo modo, Héritier não faz mais que prolongar essa luta interminável na antropologia entre o desejo de uma teoria geral do homem e os problemas particulares sobre os quais 
Revista de Antropologia, São Paulo, USP, 2004, v. 47 no 1.

cada pensamento - moderno, africano, ameríndio etc. - se debruça com exaustão. Tal a sua maior herança.

Em primeiro lugar, gostariamos de que a senhora falasse de sua trajetória intelectual. A senhora já tinha interesse pelos estudos de parentesco desde o início de sua carreira?

Eu comecei meus trabalhos de campo em 1957, mas já havia feito estudos de história e geografia. Eu me preparava para outra formação, mas já havia descoberto um pouco a etnologia - eu digo "realmente descoberto" porque antes disso eu ignorava mesmo que havia uma ciência que se chamava "etnologia", pois não havia ensino nesta área. Eu tinha colegas que se preparavam para ensinar filosofia e, como tinham de obter um certificado de ciências, eles optavam pela etnologia. Eles tinham descoberto Lévi-Strauss e me falavam dele e eu, então, fui ouvir Lévi-Strauss e fui totalmente envolvida e seduzida pelas coisas que ele dizia, das quais eu não tinha conhecimento algum. Nesses anos, eu me lembro, ele tinha 50 anos a menos, estava voltando dos Estados Unidos e fazia seminários na École Pratique des Hautes Études. No primeiro ano que eu the assisti, ele falava de coisas surpreendentes e empregava palavras impressionantes. Ele falava dos vasu das ilhas Fiji. O vasu, na língua nativa, é a instituição que permite ao sobrinho uterino pegar o que quiser na casa de seu tio materno. Ele pode pegar seus bens, mas também brincar com sua mulher e até mesmo assediá-la e casar-se com ela depois da morte do tio. As palavras que Lévi-Strauss usava eram completamente desnorteadoras. No ano seguinte, ele fez um curso sobre a caça às águias entre os Hidatsa, e tudo era desorientador. Eu descobria a etnologia e, assim, também quis obter o certificado em "etnologia". Não havia uma graduação ou um mestrado nessa área. Havia somente um 
exame pelo qual nós passávamos no Museu do Homem. Era um sistema de ensino diferente. Mas eu não tinha a intenção de me profissionalizar até o dia em que Lévi-Strauss procurou um geógrafo e um etnólogo para viajarem para o Alto Volta, que se tornou o Burkina Fasso, para fazerem uma pesquisa financiada pelo governo geral da África Ocidental Francesa. Nesse momento, esses países ainda não eram independentes e esse governo criou um projeto hidráulico que devia ser implantado nos confins do Alto Volta e do Mali: a idéia era fazer uma barragem no rio para o cultivo do arroz. E eles queriam um etnólogo e um geógrafo, e eu, então, parti para o meu primeiro campo como geógrafa em 1957.

Quando a senhora começou o trabalho de campo já tinha a idéia de trabalhar sobre as relaçôes de gênero?

Não, de modo algum. Eu não me considero uma antropóloga especialista na teoria de gênero. Eu continuei trabalhando na mesma lógica, o que me levou a ter um ponto de vista sobre as sociedades contemporâneas.

No momento de seu primeiro campo, a senhora já tinha terminado os seus estudos em geografia?

Eu tinha terminado meus estudos e era o momento de passar da história à geografia e depois à etnologia. Meu percurso foi feito a partir de uma série de acasos produtivos. Pois é preciso saber aproveitar uma chance quando ela aparece. Assim, nesse primeiro campo, nós tínhamos de trabalhar essencialmente em duas regiōes: uma extremamente populosa, com os Mosi, e outra com uma população muito pequena, que tinha de três a quatro mil pessoas, os Pana, onde nós devíamos implantar uma barragem e fazer culturas de arroz. O projeto era saber se haveria uma emigração dos jovens Mosi, que habitavam na região demograficamente populosa, para a região menos populosa e se eles traba- 
Revista de Antropologia, São Paulo, USP, 2004, v. 47 no 1.

lhariam nos cultivos de arroz. Mas esse projeto não foi realizado. Entre essas duas regióes, eu atravessei uma região muito particular de mata fechada que, de tempos em tempos, apresenta imensas clareiras de quilômetros de diâmetro que têm apenas uma espécie de árvore chamada faidherbia albida, que cresce em regiōes de criação de cabras. Ela tem a característica de perder as folhas na época das chuvas e de ganhálas na época da seca, fornecendo alimento para os animais. Nessa região, havia um interessante sistema econômico de colaboração entre populações sedentárias e os Peuls, que são nômades. Estes vinham com seus animais, que comiam a faidherbia albida na época da seca, e preparavam a terra para o cultivo. E eram grandes aldeias, muito diferentes das dos Mosi, que eram fechadas sobre si mesmas, com uma divisão em duas metades. Eu sempre parava nessas aldeias para conversar com as pessoas e me dei conta de que era o lugar onde eu gostaria de realizar pesquisas de campo...

\section{E essas populaçôes falavam a lingua francesa?}

Não, nós precisávamos de um intérprete. Os intérpretes foram indispensáveis mesmo depois que eu já falava bem a língua local. Meu intérprete, que foi sempre a mesma pessoa, era um griot, que pertencia a uma casta particular e conhecia a memória local. Ele sabia as genealogias, conhecia todo mundo e circulava entre todas as aldeias durante as festas. Era uma maneira mais fácil de me aproximar dessas pessoas que eu ainda não conhecia. O outro motivo de ter um intérprete tem uma função utilitária: mesmo quando nós compreendemos a língua e falamos, ela é sempre dúbia. Porque, quando fazemos anotaçōes, temos um tempo para escrever mas, quando é o intérprete que traduz o que você diz, a pessoa que ouve recebe a tradução de uma certa maneira. Se ela não entender, vai fazer uma pergunta na sua língua ao intérprete, que vai lhe responder. E eles vão debater o que eles entendem sobre a questão. Mas, 
como eu entendo o que eles dizem, o mais importante é acompanhar o debate entre eles e isto permite uma maior profundidade sobre o assunto. Porque se eu mesma tivesse feito a pergunta, eles não perguntariam o que eu queria dizer e eles tentariam me responder diretamente num primeiro sentido, uma primeira interpretação. Então, eu sempre tive um intérprete por três razões: em primeiro lugar, porque possibilitava uma introdução e uma relação ternária e não apenas dual; em segundo, pelo tempo de latência que me permitia pensar, escrever e anotar; e, em terceiro, pelo suplemento de informações que eu obtinha graças às conversas entre o intérprete e o interlocutor. E eu volto ao que eu falei no início: os Samo se encontravam nessas aldeias que eu tinha vontade de voltar e, nas missões seguintes, quando eu entrei no CNRS (Centre Nationale de Recherche Scientifique), eu retornei aos Samo porque eu achava que, por trás desse sistema econômico particularmente sedutor, havia informações que ainda eram pouco conhecidas. Eu não vou entrar em todos os detalhes mas eu me interessei especialmente pelo parentesco. Porque todos que haviam me precedido - incluindo Marcel Griaule nos anos 1930 - não tinham se interessado verdadeiramente sobre as questões de parentesco, limitando-se a recolher um vocabulário extremamente breve, que não podia dizer grande coisa.

\section{Quando, então, a senhora começou a pesquisa entre os Samo?}

Deve ter sido por volta de 1962-1963. Mas antes eu trabalhei no Instituto Nacional de Estudos Demográficos para explorar o material que eu havia recolhido. E fui selecionada para um cargo no CNRS a partir dos trabalhos publicados sobre os Pana e os Mosi dessa primeira missão. Então, eu tinha o propósito de fazer um levantamento mais aprofundado das terminologias de parentesco. Não existia nada sobre os Samo. Os Pana não eram conhecidos. Os Mosi eram conhecidos, mas 
Revista de Antropologia, São Paulo, USP, 2004, v. 47 no 1.

não havia nada sobre o seu sistema de parentesco. Havia textos sobre os Mosi, escritos pelos administradores do governo colonial e pelos missionários, mas nada de científico. Eu sabia que não havia informaçōes e se ignorava a natureza dos sistemas de parentesco africanos. Então, eu me dei conta da dificuldade que havia de recolher terminologias de parentesco completas e longas. É extremamente difícil haver uma representação mental nítida e precisa do que é uma situação de parentesco quando ela é descrita ao longo de uma cadeia. Se eu digo: "Qual o termo de parentesco que você usa para descrever a filha do irmão da mãe do seu pai?". É extremamente simples. É uma prima de sexto grau no sistema romano. Mas é mais difícil representar o parentesco do outro do que o de si mesmo. Eu perguntei sobre essa menina e eu tinha de traduzir no sentido deles. Em vez de dizer "a filha da filha", eu dizia "você, seu pai, sua mãe, seu irmão, sua filha”. Mesmo assim não era nada simples. Há o modo tradicional de proceder: mostrar a genealogia aos informantes e perguntar como eles chamam os indivíduos que ocupam as diferentes posições. Mas, nesse método, pode haver dois obstáculos. Primeiro, o de não haver indivíduo em carne e osso para ocupar essa posição e, em seguida, não haver ocasião para nomeá-lo. O segundo obstáculo, mais complicado e que pode destruir toda a pesquisa, é que, quando você tem posiçôes nesse nível, é muito provável que o indivíduo ligado a Ego - por exemplo, a prima - pode ser ligado a ele também por outro caminho. Ou seja, ela é a filha da filha do irmão da mãe do seu pai, mas pode ser também a filha do filho da irmã da mãe da sua mãe. São os mesmos indivíduos, mas há duas cadeias que os unem. $\mathrm{E}$ talvez mais de duas. Ora, quando há um parente que é ligado a Ego de diferentes maneiras, escolhe-se a nomenclatura mais próxima. Suponhamos que essa pessoa deva ser chamada "minha irmã" ou "minha sobrinha" e que, entre essas duas opçôes, "minha irmã" seja a mais próxima. Assim, você diria "esta 
menina eu a chamo 'minha irmã'”, e nós podemos acreditar que o termo "irmã" seja uma função desta ou de outra cadeia. Isto somente para mostrar que uma mesma pessoa pode estar relacionada a múltiplas redes, a nomenclatura não corresponde a apenas uma rede e que não é necessariamente aquela que o pesquisador está tentando reconstituir. Assim, foi preciso inventar um sistema de coleta de terminologias e usar a inteligência. Meu sistema era simples: baseado em pequenas pedras que representavam os homens, o sexo masculino, e pequenas conchas, que serviam como moeda local, que representavam o sexo feminino. $\mathrm{E}$ palitos de fósforo para representar as relações. Então, eu construía os esquemas dizendo: “Aqui é você, seu pai, sua mãe, seu irmão...”. E eles me liam: "Eu chamo meu pai assim, a mãe do meu pai assim, o irmão da minha mãe assim...". E eu aprendi que um indivíduo, para saber como ele deve chamar alguém, não parte de si mesmo, mas de seu pai ou de sua mãe, que são os primeiros da sua rede, e ele estuda as nomenclaturas que seu pai e sua mãe pronunciam. Ou seja, há uma dedução. Isto é muito importante para compreender como as crianças aprendem a se encontrar dentro de um sistema de parentesco. Elas aprendem como seus pais chamam esses indivíduos e, em seguida, tiram suas deduções. São sistemas de derivação que são inculcados às crianças. Mas, sobretudo, eu descobri um estranho sistema de parentesco e eu achava que estava errada. Eu refazia o sistema baseada em vários informantes, homens e mulheres, e encontrava as mesmas constantes. Isso significava que a coleta estava boa mas eu não sabia o que tinha diante de mim. Foi retornando do meu segundo campo, o primeiro entre os Samo, ao conversar com Lévi-Strauss e ler a literatura que ele me indicou, que eu percebi ter um sistema de parentesco de tipo omaha. E naquela época ignorava-se que havia esses sistemas de parentesco na África. Esses eram somente encontrados na América do Norte. 
Revista de Antropologia, São Paulo, USP, 2004, v. 47 no 1.

Como a senhora procedeu nesse estudo de um sistema que seria mais tarde designado como "semicomplexo"?

Meu primeiro ponto foi recolher atentivamente esse sistema. $\mathrm{O}$ interessante é que as pessoas construíam elas mesmas seus esquemas. E eu podia verificá-los no meu catálogo. Mas a ordem lógica que usei para construir minhas pesquisas não era necessariamente a mesma que a delas. Quando eu descobri que era um sistema do tipo omaha, eu já tinha trabalhado sobre uma célebre conferência de Lévi-Strauss intitulada "The future of kinship studies", na qual ele explicava o trabalho que havia realizado sobre as estruturas elementares de aliança, as dificuldades que encontrou em relação às estruturas complexas e os diferentes métodos para compreender como elas funcionavam. Ele via um método baseado em cálculos matemáticos ou simulaçōes. Ele mostrava que, entre os sistemas elementares e complexos, havia os sistemas crow e omaha e que seria uma boa opção começar por compreender como eles funcionavam. E como eu havia encontrado uma estrutura que chamei de "semicomplexa", busquei encontrar essa resposta. Mas eu não utilizei os métodos matemáticos, e sim a verdade etnográfica, quer dizer, trabalhando sobre os casamentos realizados em um grande número de gerações. Realizei, então, uma pesquisa genealógica em três aldeias que representavam um conjunto, onde as pessoas casavam entre si. E, depois disso, elaborei um longo trabalho de análise desses dados que durou mais de 20 anos. Foi preciso inventar um método eletrônico com a ajuda de um engenheiro em informática. Isso resultou no livro L'Exercice de la parenté (1981), onde eu mostro que os sistemas semicomplexos de aliança funcionam de acordo com regras negativas e proibitivas. Isso levava, à primeira vista, a afirmar que os indivíduos eram obrigados a escolher seus parceiros extremamente longe. Mas eu mostrei que a combinação de regras proibitivas de aliança tinha um efeito mais de subtração do que qualitativo e que, longe de obrigar as pessoas a escolher seus côn- 
juges em lugares geograficamente distantes, havia um tipo de endogamia local, com a condição de se esperar um número de gerações que implicavam interdições absolutas: você não podia se casar com a linhagem da sua mãe, nem da sua linhagem, no caso de uma sociedade patrilinear, nem com a linhagem das suas duas avós. Isso representa já quatro linhagens proibidas. Além disso, você não pode se casar com as linhagens das suas esposas precedentes nem dentro de uma linhagem onde alguém que você chama de "meu irmão" ou "meu pai” já recebeu uma esposa. É por essa razão que nós pensávamos que havia uma grande dispersão. Você não pode se casar dentro da linhagem da mãe de sua mãe, mas isso se torna possível quando você sobe uma geração. Eu mostro que esses casamentos são os privilegiados - eu os chamo de "fechamentos consangüíneos" (bouclages consanguins) - e que também há casamentos regulares entre as linhas de uma mesma linhagem. Eu simplesmente pus em evidência um problema de simetria que possui duas naturezas. A simetria paralela é uma simetria entre indivíduos do mesmo sexo, e a simetria cruzada entre indivíduos de sexo diferente. Assim, eu mostrei que esses sistemas favoreciam uma endogamia de aldeia, e não uma dispersão de alianças, com a condição de mudar de linha a cada geração. As trocas de irmãs podem ser feitas, mas com a condição de mudar de linha a cada geração no interior de uma mesma linhagem.

\section{L'Exercice de la parenté foi sua tese de doutorado?}

Sim, mas eu não a defendi porque, nesse meio tempo, eu fui eleita para o Collège de France, e seria um pouco ridículo defender a tese já estando lá. Mas minha tese - compreender o desenvolvimento e as modalidades do funcionamento dos sistemas semicomplexos - foi uma descoberta. Representou um enorme trabalho que depois me levou a me interessar por outras questões. Eu descobri que a teoria de RadcliffeBrown sobre a unidade de parentesco, baseada no sistema terminológico, 
não dava conta de todas as situações possíveis. Grosso modo, a teoria de Radcliffe-Brown dizia o seguinte: que um Ego olhava para toda a linhagem da mãe como mães masculinas ou mães propriamente ditas. Mas se nós mudarmos de perspectiva, se passarmos para o interior dessa linhagem, percebemos que há um tipo de termo para os filhos da irmã do pai que é aplicado também aos filhos da irmã do pai do pai, da irmã do pai do pai do pai etc. Assim, todas as mulheres, ou melhor, todas as irmãs dos homens da linhagem, em relação a um Ego masculino, são consideradas como se fossem irmãs do Ego. Do ponto de vista de Ego, os filhos dessas mulheres são considerados "sobrinhos". São filhos de irmãs. Então, havia uma estrutura de nomenclaturas que operava uma espécie de rebaixamento de todas essas mulheres. Eu chamei isso de "valência diferencial dos sexos", que também encontramos em outros tipos de sistema. Por exemplo, nos sistemas crow, que são matrilineares, nos quais nós poderíamos encontrar o inverso, esse tipo de nomenclatura pára quando a progenitura real introduz seus direitos. Ou seja, uma mulher não pode chamar de "meu pequeno irmão" e "meu sobrinho" um homem mais velho que ela; enquanto que, no sistema omaha, um homem pode chamar uma mulher de "minha irmã" e "minha pequena irmã", mesmo se ela for muito mais velha que ele. Se o sistema crow fosse até o fim, isto implicaria que as mulheres poderiam, para dizer de uma maneira grosseira, ser "superiores" aos homens. Mas se os sistemas crow são matrilineares, isto não quer dizer que as mulheres são consideradas superiores aos homens.

No caso omaha, "superioridade" significa sempre dominação? E, tendo em vista a assimetria em relação ao caso crow, podemos afirmar que a dominação é sempre masculina?

Estou falando de uma relação dada pela nomenclatura. Eu nunca disse que, socialmente, isso implicaria relações marcadas pela autorida- 
de, de um lado, e obediência necessária, de outro. Quando se chama alguém de "mãe", mesmo se é uma criança, não é possível se relacionar com ela de maneira brutal, vulgar ou erótica. Isso induz um tipo de comportamento. Eu digo simplesmente que a estrutura da língua diz algo sobre a relação entre os sexos. O lado feminino é considerado, nesse sentido, como inferior. Por exemplo, no sistema iroquês, um homem pode ter irmãs mais novas, mas uma mulher só pode ter irmãos mais velhos. Eu mostrei que há uma regra da "valência diferencial dos sexos", que está inscrita em pelo menos quatro dos seis grandes tipos estruturais de parentesco. Essas equivalências universais significam que aquele que nasce antes é superior ao que vem depois. A relação anterior-posterior equivale à relação superior-anterior. Essa constante universal está baseada numa observação real: os pais nascem antes dos filhos. A relação masculino-feminino está inscrita na terminologia, como se fosse uma relação mais velho-mais novo, anterior-posterior, superior-inferior. Nós encontramos isso também na mitologia, na qual os homens são criados primeiro. No direito romano, por exemplo, diz-se que a esposa ocupa o lugar da filha. A esposa não tem a mesma igualdade de direitos que o marido. Isto também está presente na maioria das legislaçóes: o fato de que não podemos usar um Ego feminino como sujeito de direito. As mulheres estão presas nas relaçôes de simetria e de reciprocidade. Quando todas as leis - judaicas, do Corão, gregas, romanas, as nossas leis dizem que um homem não pode se casar com tal e tal mulher, sua irmã por exemplo, é considerado inútil dizer que uma irmã não pode se casar com seu irmão. A reciprocidade elimina um certo número de interdições em relação às mulheres. Isso é igualmente verdadeiro em termos de simetria: se dissermos que um homem não pode se casar com a filha do seu tio materno, deveríamos dizer simetricamente que uma mulher não pode se casar com o filho do seu tio materno. Mas isso nunca acontece. 
Revista de Antropologia, São Paulo, USP, 2004, v. 47 no 1.

Então, de uma maneira geral, a mulher não é considerada sujeito?

A mulher não é considerada sujeito de direito. Pois há situações de parentesco que deveriam ser ditas no feminino. Mas, como não podemos, juridicamente falando, dizemos, por exemplo, que um homem não pode se casar com as duas irmãs e sua mãe ao mesmo tempo. É o título do meu livro Les deux soeurs et leur mère, sobre o incesto de segundo tipo. Há toda uma literatura de historiadores para tentar encontrar as razôes pelas quais um homem não pode se casar com duas irmãs e sua mãe. Uma mulher não pode se casar com o marido de sua mãe, uma mãe não pode se casar com o marido de sua filha, e uma irmã não pode se casar com o marido da irmã. São as posições simétricas das posições que dizem que um homem não pode se casar com a mulher do seu pai, nem com a mulher do seu filho, nem com a mulher do seu irmão. São proibiçôes que perduram até os nossos dias. A lei francesa só muito recentemente permite o casamento com a esposa do irmão depois da sua morte (a partir de 1918) e depois do divórcio (a partir de 1984). Estava dito para os homens, mas não estava dito para as mulheres. A partir da idéia "duas irmãs e sua mãe", há toda uma reflexão sobre a noção de incesto e do incesto de segundo tipo.

A noção de "incesto de segundo tipo" serve para pensar somente os sistemas complexos e semicomplexos ou pode ser usada também para os sistemas elementares? Há casos, na Amazônia indigena, por exemplo, nos quais é bastante comum um homem casar-se com duas irmãs.

O incesto de segundo tipo não é específico apenas aos sistemas complexos e semicomplexos, mas ele não é universal. Certamente essa questão mexeu com a humanidade, que responde seja com a negativa seja com a positiva, mas mais freqüentemente com a negativa. A questão de saber o que se passa quando tocamos na idéia do idêntico pode ser respondida de duas maneiras: produzem-se catástrofes ou boas coisas. 
Na verdade, essa é a chave da resposta, podemos responder "é mau" ou "é bom". Na maioria das vezes que dizemos "é mau", vai ser totalmente proibido. O meu postulado é que o incesto de primeiro tipo, aquele que se dá entre consangüíneos, é somente uma parte da visão mais ampla sobre a teoria do incesto, que é baseada na idéia da identidade. Mesmo em sociedades que proíbem o casamento com duas irmãs, há situações interessantes. Entre os Mosi do Burkina Fasso, um homem não pode se casar com duas irmãs, salvo se elas forem gêmeas, porque, se forem gêmeas, elas serão a mesma pessoa em dois corpos. Nesse momento, ele até mesmo é obrigado a se casar com as duas. Assim, há variaçôes que dependem de concepções locais em relação à idendidade e ao mal causado pelo contato entre corpos idênticos.

Isso significa que a identidade é, antes de tudo, a partilha de uma mesma substância?

Sim. Ela permite compreender um certo número de proibições que o pensamento cristão sempre tentou explicar dizendo que o casamento faz dos indivíduos a mesma carne. Era a única maneira de dizer que um homem não podia se casar com a irmã da sua esposa e que uma mulher não podia se casar com o marido da irmã. Essa é a teoria cristã. Já a teoria do incesto de segundo tipo supõe que os indivíduos sejam substancialmente os mesmos. O incesto de segundo tipo se dá sempre entre dois consagüíneos. Ou seja, se um homem dormir, por exemplo, com a irmã da sua esposa, ele vai trazer para a esposa alguma substância da primeira. Falamos de algo extremamente físico, que perdura na substância dos indivíduos, que passa uns aos outros por meio de um mesmo mediador. Essa idéia continua a existir nas sociedades modernas somente para os animais. Nós sempre ouvimos falar que, se uma cadela de raça cruzar com um cão bastardo, certamente ela terá filhotes bastardos por causa da idéia de impregnação. Essa é uma reminiscência da idéia de 
Revista de Antropologia, São Paulo, USP, 2004, v. 47 no 1.

substância e da passagem de um corpo a outro. Idéia que nós encontramos também no nazismo, no qual se dizia que, se uma ariana tivesse relações com um judeu, ela teria crianças judias. Assim, eu tentei evidenciar que o incesto de segundo tipo estava subjacente e que o contato de duas substâncias idênticas por meio de um terceiro não era nunca considerado como algo importante.

A teoria do parentesco e da aliança de Lévi-Strauss ganhou diversas leituras. Louis Dumont, por exemplo, privilegiou a relação entre pessoas do mesmo sexo, que ele designou como relaçôes de afinidade. Já a senhora preferiu evidenciar a relação entre os sexos, dada em um primeiro momento na relação de germanidade cruzada. Como a senhora pensa a sua filiação em relação ao pensamento de Lévi-Strauss?

Minha filiação a Lévi-Strauss é evidente. Eu tentei perseguir os caminhos que ele começou a trilhar e comecei onde ele parou. Eu sou fundamentalmente estruturalista num sentido um pouco diferente do dele. $\mathrm{O}$ certo é que sou universalista. Eu não sou relativista. Eu penso que cada cultura traz uma resposta particular a uma série de questóes, mas pensar cada uma delas como incomparáveis entre si nos impede de pensar que há uma ciência do homem. Cada fórmula representa uma faceta particular que nos permite colocar em evidência as regularidades e as leis. Por exemplo, nós sabemos que existem seis sistemas de filiação. Isso é uma lei. Nós podemos mostrar que há leis que regem nosso universo social. É mais fácil no mundo do parentesco do que nos outros, mas um dia essas leis estarão mais claras em outros domínios. Eu sou estruturalista de maneira ligeiramente diferente da de Lévi-Strauss, porque eu introduzi o corpo. Não quero dizer que Lévi-Strauss negue a realidade, pelo contrário, ele é muito próximo do concreto, mas ele não evidenciou o corpo nas suas teorias. Isso acarretou várias críticas, como a da extrema abstração, que é totalmente falsa. O que é verdadeiro é que 
ele não levou em conta o dado biológico. Por exemplo, a valência diferencial dos sexos nunca apareceu na sua obra. Ele diz que a relação irmão-irmã, a relação cruzada, é totalmente diferente da relação entre dois irmãos e entre duas irmãs, mas ele não viu a valência diferencial dos sexos, e eu acho que esta é uma questão geracional e cultural. Ele simplesmente não viu, como os homens de sua época, pois era considerado normal que as mulheres fossem dependentes dos homens.

Nesse sentido, a "valência diferencial dos sexos" seria, de certa forma, logicamente anterior à proibição do incesto?

Ela é o que permite compreender a proibição do incesto. Eu visualizo as coisas da seguinte maneira: é como se você pegasse quatro fuzis que não podem se manter em pé sozinhos, mas, quando você os apóia uns sobre os outros, eles conseguem se manter em pé. E eles se mantêm em pé ainda melhor quando você faz uma ligação entre eles. Segundo LéviStrauss, a proibição do incesto, a exogamia, o casamento e a divisão sexual do trabalho são os quatro pilares do social. Mas eu digo que eles só se mantêm juntos porque há a valência diferencial dos sexos. Assim, não poderia haver proibição do incesto se os homens não tivessem a idéia anterior de que eles tinham o direito sobre suas filhas e irmãs, e não o contrário. Porque, se não houvesse essa idéia, poderíamos encontrar um número equivalente no mundo de sociedades onde as mulheres trocassem seus homens entre elas ou sociedades em que os dois sexos trocassem entre si. Ora, encontramos em todas as sociedades uma única e mesma regra: são os homens que trocam, e não o contrário. Assim, meu estruturalismo é ligeiramente diferente do de Lévi-Strauss por essas duas razôes: a representação do corpo, com as substâncias corporais que explicam o incesto de segundo tipo, e a valência diferencial dos sexos. E há uma terceira razão, mais geral e abstrata, que diz respeito à idéia que Lévi-Strauss usou para justificar o binarismo e lhe serviu para a análise 
Revista de Antropologia, São Paulo, USP, 2004, v. 47 no 1.

dos mitos, a idéia de que o cérebro humano funciona a partir de um número limitado de conexões. Ora, essas teorias eram certamente válidas há 30 ou 50 anos, mas elas não o são mais por conta do avanço das neurociências. E nós sabemos que é justamente essa capacidade de fazer conexões que nos falta quando nascemos. Quando nascemos, temos neurônios, mas ainda fazemos muito pouco sinapses, que são as relaçôes entre os neurônios. Uma pessoa que teve um acidente cerebral, e teve uma parte das suas sinapses destruídas, pode reaprender a usar seus membros, o que implica a ativação de outras sinapses, outros circuitos no cérebro. Graças às ressonâncias magnéticas, sabemos hoje que as crianças realizam muito pouco sinapses e que elas se desenvolvem progressivamente durante o aprendizado ao longo da vida. Aos 20 anos, temos milhares e milhares de sinapses - algumas vão desaparecer para serem substituídas por outras. É uma construção que se faz durante toda a infância e a juventude. Então, para mim, essas categorias binárias não vêm desse sistema de conexões preexistente. Esse sistema de conexões cerebral é construído a partir das nossas experiências. Como nós introduzimos essas categorias binárias? Não podemos escapar a essa categorização desde os nossos mais longínquos ancestrais, seja o Neandertal seja o Sapiens sapiens. Eu penso que o binarismo é função, no espírito, da tomada de consciência das suas origens pelos humanos. O que é próprio no humano - e vale também para nossos ancestrais - é que, diante do desconhecido, ele faz uma relação com aquilo que ele já conhece. Há o que eu chamo de "limites do pensamento". Nas estaçôes de trem, no final da plataforma, há cilindros metálicos onde os trens se apóiam. Eles se chamam butoirs [limites, freios]. Então, um "limite do pensamento" significa que o pensamento não pode simplesmente ultrapassar para o outro lado. É um limite que não podemos passar e somos obrigados a nos acomodar. Por exemplo, todas as espécies animais têm a mesma constante: há masculinas e femininas, machos e fêmeas. Então, isso é 
R. Sztutman \& S. Nascimento. Antropologia de corpos e seXos...

um postulado que é a base de uma grande oposição mental entre coisas semelhantes e coisas diferentes. Em relação a mim, todas as mulheres são semelhantes a mim e todos os homens são diferentes. Para um homem, todos os homens são semelhantes e as mulheres diferentes. Então, a diferença entre os sexos é a base para a oposição idêntico e diferente.

Não estaríamos, aqui, de volta ao plano da "lógica das qualidades sensiveis" como apontada por Lévi-Strauss?

Sim, perfeitamente. Todas as outras categorias dependem desse modelo. Cada um dos termos só é compreensível em função da existência do outro. Não há o alto sem o baixo, o macho sem a fêmea. Todas as categorias dependem desse modelo e as categorias binárias existem a partir da diferença fundamental entre masculino e feminino. Há também outras diferenças fundamentais, como o dia e a noite. O problema é saber por que há uma hierarquia no interior dessas categorias. E essa hierarquia é perceptível em todas as sociedades, não há exceção.

Qual o estatuto da noção de biológico empregada pela senhora? Em Masculin/féminin, por exemplo, a senhora menciona a idéia de "um dado biológico de base" mas que não teria uma relação direta com a idéia de natureza...

O biológico é um dado real, da observação. Entre as observações, há aquelas que são morfológicas e outras fisiológicas. Eu assumo tudo isso como biológico, como diferenças de forma. É o concreto, são observações de dados visíveis, e eu não posso dizer outra coisa. Eu não penso que há uma definição do masculino e do feminino por natureza. Quando eu falo em uma observação da biologia, é por uma comodidade de linguagem. É evidente que existe uma assimetria funcional. Que as mulheres concebem as crianças sozinhas é uma evidência, assim como para o mundo animal. Esses dados estiveram sempre lá e eles coman- 
Revista de Antropologia, São Paulo, USP, 2004, v. 47 no 1.

dam nossos tipos de reaçóes. O que mudou foram os modos de observação a partir da descoberta das lentes, da óptica. E isso não quer dizer que descobrimos grande coisa. Foi somente no século XVIII que começamos a entrar um pouco na intimidade dos corpos e descobrir que havia gametas sexuais, óvulos e espermatozóides. Durante um longo tempo, pensávamos que todo o embrião era a cabeça do espermatozóide ou era inteiramente um óvulo. Foi preciso muito tempo para que os modos de apreensão do real mudassem. $\mathrm{O}$ simples fato de que esses modos de apreensão mudaram nos permitiu compreender que se passa outra coisa no domínio da procriação, e que não se trata simplesmente de colocar a semente do homem num terreno fértil. Isso não significa que as representaçôes antigas desapareceram. Nós demoramos milênios para construir os sistemas de representação e nos faltará não menos tempo para os desconstruir. O que eu quero dizer é que será sempre em função da observação do real. Como podemos imaginar que teremos idéias que não sejam criadas em função de uma relação com a realidade? Tanto a filosofia quanto a teologia são, certamente, abstraçôes, mas partem de questôes sobre a vida e a morte, sobre a sexualidade. Não há idéias puras. Mesmo em relação à matemática. Assim, a observação do real é, necessariamente, a base do pensamento. Um animal observa o real mas ele não pensa. Nós somos munidos para pensar, mas não pensaríamos se fôssemos apenas espíritos puros. Não imagino um espírito puro sem corpo. O corpo e o pensamento são duas coisas que andam juntas.

Poderiamos dizer, assim, que a sua teoria dá um corpo ao espirito transcendental presente em Lévi-Strauss...

Sim, se vocês quiserem, eu lhe dou um corpo. 
No que diz respeito à "valência diferencial dos sexos", por que ela conduz necessariamente à hierarquia?

É um grande mistério, é um limite do pensamento. A humanidade se confrontou com mistérios que duraram muito tempo, um deles é o fato de que as mulheres têm um privilégio incompreensível, injustificado, injusto, exorbitante: aquele de fazer o diferente. Que as mulheres façam filhas, nós aceitamos. Mas a questão é: como as mulheres fazem o diferente delas mesmas, como elas podem fazer filhos? É uma questão, metafísica e prática, extremamente séria. Muitos mitos tentaram racionalizar essa questão buscando entender por que os homens não tinham essa capacidade de fazer o mesmo que elas. Alguns mitos explicam que, no início, os homens faziam seus filhos e as mulheres suas filhas. Tanto na Austrália quanto na África encontramos esses mitos. Eles dizem que foi preciso uma aventura, qualquer que seja, que fez com que os homens fossem desprovidos do direito de fazer seus filhos em prol das mulheres. Outros mitos explicam, notadamente na Ásia, que ainda há, em algum lugar do oceano, ilhas onde cada sexo reproduz seu semelhante. Os mitos não explicam mas eles dizem que existem ilhas onde as mulheres fazem suas filhas sozinhas, ou que elas são feitas pelo vento ou pelo sopro divino, mas, em todo caso, nunca são feitas pelo esperma dos homens. Há também as teorias que explicavam como se faziam as crianças: pelo modo de fermentação, cozimento, mas não se sabia que havia um gameta masculino e outro feminino. Assim, a humanidade precisou de uma resposta que, de certa forma, favorecesse o gênero masculino. Há teorias hoje que dizem: não são as mulheres que decidem. Elas têm, ao nascer, pequenos grãos que são colocados lá por Deus, por gênios ou por espíritos ou, mais freqüentemente, pelos ancestrais. Esses grãos descem, um após o outro, pela vagina e são regados por um homem. Se ele não regar esses grãos, a criança não vem ao mundo. Assim, há potencialidades nas crianças que são herdadas dos ancestrais ou de 
Revista de Antropologia, São Paulo, USP, 2004, v. 47 no 1.

Deus por meio de um instrumento, que é o esperma. A mulher é como um depositário, um receptáculo, mas ela não é o motor. Essa história dos grãos está presente em Malinowski, nas ilhas Trobriand. Há um documentário sobre os Zulu, que passou recentemente na televisão, que mostrava a vida de uma família polígina, com esposas de um mesmo homem, que viviam numa aldeia. $\mathrm{O}$ marido era operário e vinha regularmente visitar suas esposas. O comentador contava: "o papel do homem é de trazer dinheiro para alimentar as crianças e regar os grãos”. Esse comentário foi reproduzido no Le Monde, que dizia que era uma bela metáfora sobre o ato sexual.

$\mathrm{O}$ segundo pacote de teorias encontrado em nossa sociedade, que herdamos do modelo grego e vemos espalhado para todo lado, está ligado ao modelo aristotélico, e também o encontramos em outras sociedades que não conheceram este pensamento, como os Navajo. Essas teorias dizem que é a semente do homem que põe crianças dos dois sexos dentro da mulher. Há uma espécie de combate entre ambos, um combate noturno, invisível e, dependendo de quem ganhe, nasce uma menina ou menino. Aristóteles, em $A$ geração dos animais, apresenta o feminino como matéria que prolifera de maneira monstruosa e deve ser dominada pelo pneuma, que é o sopro, o espírito, a forma, a idéia, a vida. E tudo isso está no esperma. O pneuma é transmitido pelo homem, que possui várias potencialidades. A primeira é genérica, a potência masculina; a segunda é particular, de um homem em particular; e a terceira, que varia segundo as circunstâncias, é a potência “em ato", como diz Aristóteles, de acordo com a idade, a doença, as estações do ano etc. $\mathrm{O}$ arranjo entre essas três potencialidades, normalmente, deve fazer nascer um menino, que se pareça com seu pai. Se a potência genérica falha, será uma menina, mas ela se parecerá com seu pai. Por sua vez, se a potência individual falha, mas a genérica está lá, será um menino, mas que se parecerá com sua mãe. Para Aristóteles, a primeira monstruosidade é 
o nascimento de meninas, porque a matéria feminina não foi dominada. A segunda monstruosidade é o nascimento de gêmeos ou trigêmeos, pois o gênero humano deve se reproduzir um a um, e não em nascimentos múltiplos como os outros animais. A terceira monstruosidade são as crianças que nascem com má-formação. A última monstruosidade são nascimentos de monstros, quando não se reconhece mais a forma humana. E o fato de que nasçam crianças sem cabeça, ou que se pareçam com répteis, por exemplo, é a prova, para Aristóteles, de que a matéria feminina é animal e que cria formas animais. Então, é preciso controlá-la pelo esperma masculino para fazer homens, para fazer o ser humano. Assim, Aristóteles pode explicar o nascimento de meninos e meninas e suas semelhanças com os pais. Esse tipo de teoria é muito freqüente. Há uma reflexão sobre a humanidade para tentar compreender o que existe desde as origens. Essa reflexão constrói um sistema conceitual que responde à seguinte questão: como as mulheres fazem crianças dos dois sexos? A conseqüência desse sistema, no plano conceitual, é que o essencial vem dos homens e nada vem das mulheres. Isso é um primeiro ponto. O segundo, social, é que, pelo fato de os homens não poderem fazer seus filhos e reproduzirem-se por si mesmos, eles se apropriaram das mulheres para poder ter as crianças que eles desejavam ter. Então, há uma desapropriação cultural e uma apropriação social pelos homens que introduzem uma hierarquia social e uma hierarquia conceitual.

Em L'Exercice de la parenté a senhora usa a noção de "valência diferencial dos sexos" e "dominância masculina". Já em Masculin/féminin, a senhora fala diretamente em "dominação" e "desigualdade". Qual o grau de afastamento entre esses termos?

No início, há a "valência diferencial dos sexos" a partir de duas observações: o que é idêntico e o que é diferente, e o fato de que os ho- 
Revista de Antropologia, São Paulo, USP, 2004, v. 47 no 1.

mens, infelizmente, não podem se reproduzir sozinhos e que são obrigados a passar pelo corpo das mulheres para reproduzirem seus semelhantes. Então, no começo, tínhamos a "valência" e a "hierarquia", uma hierarquia conceitual que se tornou durável e, para durar, fez intervirem a violência e a força. A violência e a força não são necessárias para colocar em prática a valência diferencial dos sexos, mas elas vão se tornar necessárias para dominar as mulheres, ao longo do tempo. Surgem uma série de constrangimentos, uma falta de liberdade: as mulheres não decidem sua própria sorte. Em vários países, elas não têm o direito de abortar, elas não têm acesso à contracepção e também, em vários lugares, é impensável que uma mulher recuse o cônjuge que a família escolheu e a prestação de serviços sexuais. Além da ausência de liberdade, eu acrescento a ausência de acesso ao saber, porque o saber permite criticar seu destino e permite a emancipação. É o que dizia Molière, e provocava muitos risos: o que ele esperava de sua mulher era que ela lhe fizesse uma boa comida e não que ela conhecesse a literatura. A falta de acesso ao conhecimento produz a ausência do acesso às funções de autoridade. A partir do momento em que se coloca em prática essas três ausências liberdade, saber, autoridade -, pode-se falar em dominação masculina.

Então, trata-se de uma dominação concreta e não de uma dominação conceitual?

Não podemos realizar essa distinção. Se não houvesse a dominação intelectual não haveria a dominação concreta. E a dominação concreta é para fazer durar um estado de fato. É claro que há sociedades menos marcadas pela dominação. Se observarmos as sociedades de caçadores e coletores, que pensamos ser muito próximas das sociedades paleolíticas, podemos encontrar diferentes modelos. As sociedades dos bushmen são sociedades quase igualitárias. Há a divisão do trabalho entre os sexos, mas as atividades masculinas são consideradas mais nobres e privilegiadas 
R. Sztutman \& S. Nascimento. Antropologia de corpos e seXos...

- os produtos da caça - enquanto as femininas alimentam o grupo. É uma sociedade relativamente doce. Mas há sociedades de caçadores e coletores, ou de pescadores, onde o marido tem o poder de vida e de morte sobre sua esposa. A dominação toma diferentes formas. Mas eu não digo que ela é concomitante à valência no plano conceitual. A valência diferencial dos sexos e a dominação encontram-se num continuum.

Marilyn Strathern, antropóloga inglesa, afirma que, para pensar as relações de gênero entre os melanésios, é preciso se distanciar de algumas metáforas fundadoras, caras ao Ocidente, como o poder, o direito e a mercadoria. No lugar dessas metáforas, valeria mais a pena pensar as relaçôes de gênero entre esses povos em termos de complementaridade e troca. A senhora concorda com a crítica da autora?

Eu estou muito pouco de acordo com essa maneira de ver as coisas porque supõe que a noção de complementaridade, que é também uma noção ocidental, implicaria uma igualdade. Ora, no discurso ocidental, quando dizemos "os sexos são complementares”, é sempre na boca do sexo dominante para dizer que o que esperamos do outro é uma complementaridade e nunca uma igualdade. De fato, o discurso que eu mantenho sobre o período contemporâneo é o que visa a igualdade entre os sexos. Pois a complementaridade funciona muito bem para dizer: "Já que somos complementares, você fica em casa e cuida das crianças e da cozinha e eu saio para a caça ou trato dos assuntos políticos ou da produção". A complementaridade não implica igualdade. $\mathrm{O}$ argumento da complementaridade evidencia um modo de explicação que faz perdurar a desigualdade.

$E$ a distinção entre político e doméstico também persiste?

Ela persiste. Mas por que o político deveria ser, por esssência, masculino? Ele se tornou masculino e nos fizeram acreditar que ele era por 
Revista de Antropologia, São Paulo, USP, 2004, v. 47 no 1.

essência e por natureza masculino. Mas o político pertence a todos. E os dois sexos são as suas duas metades. Quando se diz complementaridade, desconfiem, pois significa que são admitidas uma desigualdade fundamental e a impossibilidade de cada um ir ao encontro do outro. Talvez seja a maneira de vislumbrar aquilo que mantém a hierarquia, pois a complementaridade é a base da hierarquia.

Mas é possivel pensar a valência diferencial dos sexos, que é por assim dizer inexorável, sem a desigualdade?

Não, ela já está lá por causa do modelo pai-filho, anterior-posterior. Nós observamos que os pais nascem antes dos filhos e que os primogênitos nascem antes dos caçulas. Isto lhes dá poder e autoridade. A relação anterior-posterior pode se traduzir em superior-inferior e, eu digo, em masculino-feminino, que não tem nada a ver com a sucessão das gerações, pois é uma diferença entre os sexos. E como uma coisa decorre da outra? A sucessão das gerações estabelece uma série de equivalências que funcionam implicitamente nos dias de hoje. Nascer antes implica ter uma posição de poder, mas também de proteção. E a relação masculino-feminino acrescenta-se a essa relação de anterioridade-posterioridade de maneira indireta. Por exemplo, no caso romano, diz-se que a esposa ocupa o lugar da filha, como se o feminino estivesse no lugar da geração das crianças. Eu tentei explicar que é isso que implica a introdução da hierarquia nas relações masculino-feminino, mas isso só pode ser explicado, segundo minhas hipóteses, por uma outra reflexão sobre o espírito dos homens, ou melhor, dos humanos (é melhor dizer humanos pois quando dizemos homens...), sobre o fato de que a sucessão das gerações é um limite para o pensamento, pois não podemos reverter esta sucessão. Até o momento, eu enumerei vários limites para o pensamento: o fato de que há sempre dois sexos no mundo animal, a sucessão das geraçôes no mundo dos humanos e o fato de as mulheres não 
R. Sztutman \& S. Nascimento. Antropologia de corpos e seXos...

somente fazerem o "mesmo", quer dizer, meninas, mas também o "diferente", meninos.

A senhora afirma, em Masculin/féminin que, em toda parte, para que haja a filiação e a legitimidade das crianças, é preciso uma união legitima. Tomemos um caso moderno, mais especificamente, a periferia de metrópoles como Rio de Janeiro e São Paulo, em que é muito comum mulheres viverem sozinhas com suas crianças. Nesses casos, não há filiação paterna e as crianças tampouco nascem de unióes legitimas...

Se o casamento é um contrato legítimo entre famílias, entre grupos, a filiação está baseada, essencialmente, na existência deste tipo de contrato. $\mathrm{O}$ casamento propriamente dito é um verdadeiro contrato entre famílias, que é público, conhecido e se manifesta por trocas de bens, presentes etc. Nós podemos ter também filiações legítimas nas sociedades que admitem o concubinato. Mas essa união deve ser considerada oficial. As crianças, que nascem das concubinas na China, por exemplo, são consideradas legítimas. No caso brasileiro, citado por vocês, são famílias matrifocais. Mas não há, nas sociedades tradicionais, a idéia de que pode haver mulheres solteiras ou sozinhas que criam suas crianças. Nas sociedades tradicionais africanas ou na China, há vários casos em que mulheres sozinhas ou divorciadas tinham de voltar para a sua família de origem e submeter-se à tutela do pai ou do irmão ou aceitar um recasamento. Mas a idéia de que elas podem ficar sozinhas é praticamente impensável. Eu conheci, no Burkina Fasso, entre os Samo, casos raros de mulheres que viviam sozinhas com suas crianças. Elas tinham deixado o marido, foram recusadas pela tutela dos pais e tinham autonomia. Elas trabalhavam em bares, fabricavam a cerveja de milho e vendiam. Então, elas eram consideradas mulheres livres. Não eram prostitutas, eram mulheres livres, o que era uma raridade. Elas encontraram um meio de investir para ter uma independência econômica. Mas isso 
tudo é muito recente. É algo do mundo contemporâneo. Por exemplo, o Banco Mundial parte do princípio de que, para um bom desenvolvimento mundial, é preciso ajudar na liberação das mulheres e na sua educação, pois, quando se dá crédito a elas, elas são confiáveis. A partir do momento em que elas têm independência econômica e educação, elas começam a sair da opressão tradicional patriarcal. Isso corresponde a um boom econômico e a um sensível progresso no domínio da saúde. $\mathrm{O}$ próprio Banco Mundial constatou que a emancipação feminina pode significar desenvolvimento se ele for acompanhado de educação e dos meios de produção. Eu penso que esses são fenômenos modernos. Nas sociedades tradicionais, as mulheres estavam presas ao domínio doméstico e serviam à família. Elas participavam do domínio da produção, mas não eram reconhecidas e, como não tinham acesso à educação e aos meios econômicos, elas eram totalmente dependentes. A partir do momento em que elas começam a não ser mais dependentes, é possível que o laço conjugal seja menos estável. Mas, nas sociedades contemporâneas, outros fenômenos apareceram, como o desemprego, a insegurança profissional atrelada ao machismo dominante. Então, as famílias monoparentais centradas na mãe não são um retorno às origens, mas algo totalmente diferente.

Além das familias matrifocais, pensamos também nos casamentos homossexuais e na homoparentalidade.

Nossa época mistura um pouco as coisas. Hoje vemos crescer a possibilidade do casamento que chamamos "homossexual". Eu não diria "homossexual", eu diria "homossexuado", porque quando se diz "homossexual" evidencia-se uma sexualidade diferente. É preciso reconhecer a possibilidade de aceitar esse tipo de casamento. Mas essa idéia não tem nenhuma relação com a poligamia e com o incesto. No momento, há 
uma confusão quando se diz que aceitar o casamento homossexuado permitiria aceitar outras formas de união, como a poligamia ou a bissexualidade, ou o casamento entre irmãos, ou pai e filho. Minha posição é a seguinte: sem olhar para a sexualidade nem para a questão da igualdade de direitos, antropologicamente, se observarmos o que é o casamento, sabemos que foi preciso a proibição do incesto que obriga a regra da exogamia. E, para tornar essa idéia sólida, foi preciso instaurar o contrato entre famílias. O casamento é isto: um contrato entre duas famílias, não é um contrato entre duas pessoas. Quando dois indivíduos se casam, as duas famílias assinam um contrato, há testemunhas, os parentes. $\mathrm{O}$ casamento não diz nada sobre o sexo das pessoas. Sempre foi um homem e uma mulher por uma razão muito simples: era preciso assegurar a continuidade e fazer nascer crianças. No caso do casamento entre pessoas do mesmo sexo, ainda não há o reconhecimento das famílias. Mas a partir do momento em que outras maneiras de se fazer crianças se tornaram pensáveis - por adoção, inseminação artificial, procriação assistida -, podemos imaginar que a sociedade possa aceitar o casamento entre pessoas do mesmo sexo, e até mesmo que elas possam ter crianças. A partir do momento em que se tornou pensável, ele pode se tornar realizável. Mas não há nenhuma implicação da mudança da monogamia para a poligamia, nem da anulação da proibição do incesto. Para uma sociedade ocidental, como a nossa, a poligamia, ou melhor a poliginia, seria, a meu ver, absolutamente desastrosa para as mulheres. Seria um retrocesso. Em relação à homoparentalidade, há muitas objeções em relação ao futuro das crianças. Mas eu não tenho opinião a respeito disso, pois não há referências nas quais podemos nos apoiar com seriedade. Eu tenderia a pensar que há um reconhecimento social, pois o que importa para as crianças é o olhar dos outros, especialmente o do pai. No início, esse era o problema do divórcio. As crianças de pais divorciados eram tachadas na escola. E hoje ninguém presta mais atenção. A partir do momento 
Revista de Antropologia, São Paulo, USP, 2004, v. 47 no 1.

em que o olhar da sociedade muda, o mesmo vai se dar para os filhos de famílias homoparentais.

Em relação ao tema do segundo volume de Masculin/féminin, podemos dizer que a "dissolução da hierarquia" se alcança à medida que se muda a biologia?

Não. Eu afirmo que há uma diferença e uma assimetria biológica. E esta assimetria foi vivida social e politicamente em detrimento das mulheres. Dissolver a hierarquia é reconhecer politicamente, nas instituições políticas, essa assimetria e favorecer as mulheres. Nas empresas, considera-se que as mulheres são mães em potencial, proibindo-as de ascenderem profissionalmente porque se pensa que elas serão ausentes no trabalho por causa dos filhos. Esse argumento é usado constantemente. Resultado: elas são empregadas para as tarefas subalternas, mal pagas, em horários difíceis. Isso acontece em todos os países: Estados Unidos, França, Japão. Em todo caso, dissolver a hierarquia significa inverter a perspectiva, é uma medida política. Implica uma mudança no olhar. Eu cito algumas que podem se tornar possíveis: por exemplo, mudar o olhar sobre o trabalho doméstico e fazer com que os homens se ocupem de suas crianças, pois a experiência mostra que, mesmo os pais que se ocupam dos seus filhos no início, eles logo param. Os pais podem estar sempre ali, mas eles deixam todo o trabalho para suas esposas. Então, como fazer com que o trabalho doméstico torne-se interessante e atrativo para que possa ser compartilhado? Trata-se de lhe dar atestado de nobreza para que seja valorizado, que dê prestígio e dinheiro. Se os homens tivessem a possibilidade de pegar licença no trabalho para se ocupar das crianças - geralmente são as mulheres que param de trabalhar -, o trabalho doméstico poderia ser um atrativo. Seria uma mudança de perspectiva que levaria, progressivamente, os homens a achar interessante trabalhar em casa. A partir desse momento, quando 
as crianças teriam o hábito de ver seus pais pegando-as na escola, fazendo a comida, dando-lhes banho enquanto suas mães trabalham, as crianças poderiam reproduzir este modelo. Há toda uma série de medidas que poderiam ser tomadas pelo governo, mas que nunca são consideradas como um problema político. Para mim, a contracepção é fundamental para que as mulheres obtenham o estatuto de pessoa. Como elas têm a capacidade de fazer crianças dos dois sexos, elas foram colocadas numa situação de dependência. A partir do momento em que elas têm liberdade nesse domínio, elas ganham o estatuto de pessoa. A contracepção é o elemento lógico principal. É uma verdadeira revolução copernicana!

Para terminar: a senhora se considera feminista?

É claro que eu me considero feminista, mas não no sentido militante do termo, pois eu não participo dessas açôes. E eu não tenho todo o domínio sobre essa literatura.

\section{Notas}

1 Entrevista realizada em 11 e 25 de maio de 2004, no Laboratório de Antropologia Social do Collège de France, Paris.

2 Renato Sztutman e Silvana Nascimento tiveram financiamento de estágio de pesquisa em Paris pela Capes. Renato Sztutman é pesquisador do Núcleo de História Indígena (NHII/USP) e bolsista da Fapesp. Silvana Nascimento é pesquisadora do Núcleo de Antropologia Urbana (NAU/USP) e bolsista da Fapesp. 